\title{
ANALISIS FAKTOR YANG MEMPENGARUHI IMPOR GULA DI
} INDONESIA

\section{Herawati Rusdi, Wiwin Priana Primandhana, Mohammad Wahed}

Universitas Pembangunan Nasional (UPN) Veteran Jawa Timur, Indonesia

Email: hrwtrusdi@gmail.com,wiwinpriana10@gmail.com, muhammadwahed124@gmail.com

\begin{tabular}{l}
\hline INFO ARTIKEL \\
\hline Diterima \\
25 Juli 2021 \\
Direvisi \\
05 Agustus 2021 \\
Disetujui \\
15 Agustus 2021 \\
\hline
\end{tabular}

Kata Kunci: impor; konsumsi; produksi; harga gula; dan bea masuk

\begin{abstract}
ABSTRAK
Penelitian ini, mengambil judul "Analisis Faktor yang Mempengaruhi Impor Gula di Indonesia". Judul ini diambil berdasarkan fenomena yang terjadi pada tingkat konsumsi masyarakat yang banyak sekali mengkonsumsi bahan pemanis gula dan tingkat impor gula yang semakin tinggi setiap tahunnya di Indonesia. Tujuan penelitian ini adalah: (1) Untuk menganalisis pengaruh konsumsi gula terhadap impor gula di Indonesia (2) Untuk menganalisis pengaruh harga gula terhadap impor gula di Indonesia (3) Untuk menganalisis pengaruh produksi gula terhadap impor gula di Indonesia. Penelitian ini dilaksanakan di lingkup Indonesia untuk mengetahui faktor yang mempengaruhi impor gula. Dalam metode penelitian ini menggunakan cara mengumpulkan data lalu mengolah datanya sehingga dapat memecahkan masalah penelitian. Penelitian ini menjelaskan pengaruh tingkat konsumsi, harga, produksi, serta bea masuk terhadap impor gula di Indonesia tahun 2002-2019. Data yang digunakan merupakan jenis data sekunder yang diperoleh dari berbagai lembaga yang terkait, Kementrian Perdagangan Republik Indonesia (KEMENDAG), dan Badan Pusat Statistik (BPS). Hasil penelitian yang dilakukan oleh peneliti menyatakan bahwa konsumsi, harga, produksi, dan bea masuk sangat berpengaruh besar terhadap impor gula yang ada di Indonesia. Dapat ditarik kesimpulan bahwa hasil regresi liniear berganda konsumsi gula, harga gula, produksi gula, dan bea masuk impor gula secara bersama-sama berpengaruh nyata terhadap impor gula di Indonesia. Namun secara parsial hanya variabel harga gula yang berpengaruh secara signifikan terhadap impor gula di Indonesia.
\end{abstract}

\section{ABSTRACT}

This research, entitled "Analysis of Factors Affecting Sugar

$\begin{array}{lll}\text { How to cite: } & \begin{array}{l}\text { Herawati Rusdi, Wiwin Priana Primandhana, Mohammad Wahed (2021) Analisis Faktor yang } \\ \\ \text { Mempengaruhi Impor Gula Di Indonesia. Jurnal Syntax Admiration }\end{array} \\ & \text { (8).https://doi.org/10.46799/jsa.v2i8.285 } & \\ \text { E-ISSN: } & 2722-5356 \\ \text { Published by: } & \text { Ridwan Institute }\end{array}$


Keywords: import; consumption; production; sugar prices; and import duties
Imports in Indonesia". This title is taken based on the phenomenon that occurs at the level of public consumption which consumes a lot of sugar sweeteners and the level of sugar imports which is getting higher every year in Indonesia. The objectives of this study are: (1) To analyze the effect of sugar consumption on sugar imports in Indonesia (2) To analyze the effect of sugar prices on sugar imports in Indonesia (3) To analyze the effect of sugar production on sugar imports in Indonesia. This research was conducted in Indonesia to determine the factors that influence sugar imports. In this research method using a way of collecting data and then processing the data so that it can solve research problems. This study explains the effect of consumption levels, prices, production, and import duties on sugar imports in Indonesia in 2002-2019. The data used is a type of secondary data obtained from various related institutions, the Ministry of Trade of the Republic of Indonesia (KEMENDAG), and the Central Statistics Agency (BPS). The results of research conducted by researchers state that consumption, price, production, and import duties greatly affect sugar imports in Indonesia. It can be concluded that the results of multiple linear regressions of sugar consumption, sugar prices, sugar production, and import duties on sugar together have a significant effect on sugar imports in Indonesia. However, partially, only the sugar price variable has a significant effect on sugar imports in Indonesia.

\section{Pendahuluan}

Komoditas yang memegang kontribusi berguna selama perekonomian Indonesia salah satunya adalah gula, karena gula merupakan kebutuhan pokok yang relatif murah (Pertanian, 2008). Komoditas tebu sendiri sebagai materi baku pokok gula yang mewujudkan salah satu keperluan resep pokok, bahan baku pemanis dan barang makanan selepas beras (Yusuf \& Aulia, 2010). Disamping itu, gula merupakan salah satu asal kalori guna masyarakat Indonesia selain beras, jagung, serta umbi-umbian (Wiranata, 2014).

Gula merupakan salah satu produk pertanian Indonesia yang ditetapkan sebagai produk khusus bersama dengan beras, jagung dan kedelai di forum negosiasi World Trade Organization (WTO). Dengan pertimbangan utama peningkatan ketahanan pangan dan kualitas hidup di pedesaan, Indonesia berupaya meningkatkan produksi dalam negeri sebesar 4.444, termasuk mencanangkan tujuan swasembada gula yang belum tercapai. Keadaan ini disebabkan oleh belum optimalnya faktor pendukung produksi gula dalam negeri (farm and farm), dan konsumsi gula dalam negeri masih sangat tinggi. (Hairani et al., 2014). Indonesia adalah Negara yang menjadikan gula sebagai salah satu kebutuhan pangan pokok (Aushaf et al., 2020).

Adapun kegiatan dalam perdagangan internasional, kebutuhan gula juga sangat bervariasi dan gula sangat penting perannya dalam kebutuhan pangan (Wiranata, 2014). 
Perdagangan internasional terlebih dalam impor juga bukan lepas dari yang dinamakan harga. sebab harga juga mempengaruhi barang impor gula yang akan dijual untuk konsumen. Tetapi disisi lain Indonesia masih saja mengimpor gula, dikarenakan pesatnya laju peningkatan konsumsi gula tidak sebanding dengan laju peningkatan produksi secara nasional.

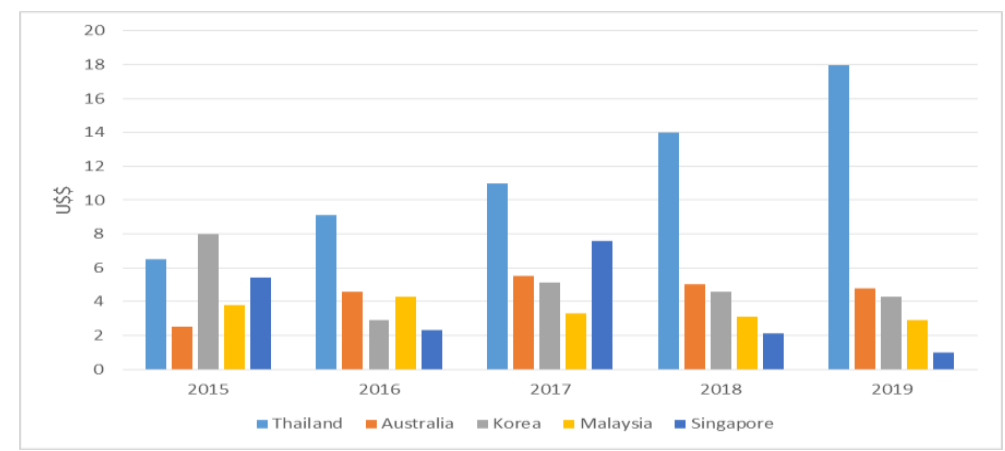

Gambar 1

Negara Tujuan Impor Gula Indonesia

Sumber : BPS Jatim 2019 (data diolah)

Negara tujuan impor gula di Indonesia yang paling banyak bersumber dari negara Thailand, hal ini menunjukkan bahwa ketergantungan negara Indonesia terhadap pasokan gula dai negara Thailand terus mengalami peningkatan di setiap tahunnya, terutama ditahun 2019. Indonesia melakukan impor gula dari Thailand dikarenakan adanya total buatan dan harga gula di negara Thailand relatif lebih rendah. Sampai saat ini Indonesia masih mengimpor gula ke negara Thailand dikarenakan produksi gula yang ada dalam negeri juga masih belum memenuhi permintaan gula di Indonesia.

Berdasarkan Dewan Gula Indonesia (Indonesia, 2009), perkembangan pada Konsumsi gula nasional meningkat dari tahun ke tahun dan peningkatan konsumsi gula nasional belum dapat dipertahankan. Dengan keahlian pembuatan gula putih nasional yang tinggi pula. Industri gula di Indonesia tidak bertahan lama untuk merasakan masamasa keemasannya. Suasana perekonomian yang tidak stabil pada masa kemerdekaan membentuk salah satu lantaran penurunan produksi gula di Indonesia. Budidaya tebu merupakan subsistem dari industri gula yaitu sebagai penghasil bahan baku tebu yang akan diubah menjadi gula. Pabrik gula merupakan subsistem yang mengolah tebu menjadi gula.

Namun, swasembada gula yang diharapkan menghadapi beberapa tantangan dari segi on-farm, off-farm, manajemen, dan partisipasi pelaku industri gula. Seperti pemerintah, petani tebu dan PG sendiri. Untuk membatasi ruang lingkup saat ini, diperlukan pendekatan sistematis untuk membangun model yang mewakili sistem industri gula dan dinamika saat ini di Jawa Timur, dalam rangka meningkatkan produksi gula dan pendapatan produsen tebu di Jawa Timur. Saya harap model yang dibangun bisa Simulasi untuk menghasilkan rekomendasi kebijakan yang tepat (Yunitasari et al., 2015). 


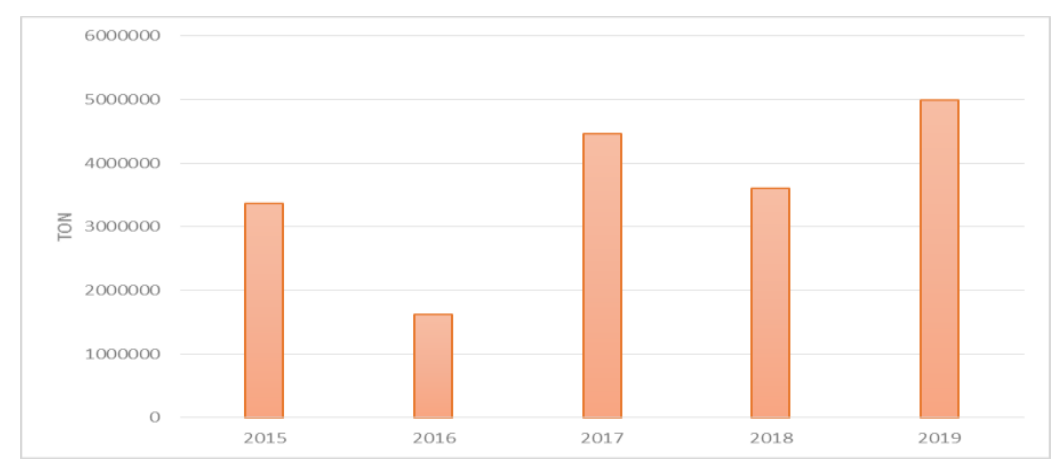

Gambar 1

Impor Gula Indonesia

Sumber : BPS Jatim 2019 (data diolah)

Berdasarkan gambar diatas terlihat bahwa angka Impor Gula meningkat, di tahun 2019 sebesar 38,64\% (Statistik, 2018). Impor meningkat dikarenakan untuk melengkapi seluruh Permintaan masyarakat akan barang-barang kebutuhan pokok yang tidak dapat dipenuhi oleh produksi dalam negeri. Gula juga merupakan komoditi penting bagi seluruh masyarakat Indonesia bahkan bagi masyarakat yang ada di dunia. Produksi gula pasir di dalam negeri ini semakin tidak mampu memenuhi kebutuhan masyarakat itu sendiri, sehingga kekurangan tersebut harus ditutupi dengan gula impor yang terus meningkat lagi dari tahun ke tahun dimana pada tahun 2017 Indonesia telah menjadi pengimpor gula terbesar kedua di dunia setelah Rusia.

Ada banyak faktor yang menyebabkan Indonesia menjadi negara pengimpor gula, salah satu faktor utamanya yaitu ketidakmampuan industri gula dalam negeri untuk memenuhi kebutuhan dan permintaan gula masyarakat yang terus meningkat dan tingginya harga jual gula dalam negeri (Wiranata, 2014). Menurut data BPS, Indonesia melakukan impor gula tersebesar di Negara Thailand dan India. Hal ini dikarenakan meningkatnya pendapatan perkapita masyarakat setiap tahunnya. Namun dari berbagai masalah tersebut banyak kendala yang dihadapi pemerintah, mulai dari semakin sempitnya lahan untuk ditanami tebu di pulau Jawa sehingga kapasitas produksi pabrik gula menjadi tidak optimal. Dari kesemua masalah tersebut menjadikan industri gula tidak efisien dan tidak mampu bersaing di pasar dunia.

Kondisi menurunnya produksi gula dalam negeri tidak berbanding lurus dengan konsumsi gula dalam negeri yang selalu mengalami perubahan dan cenderung mengalami peningkatan pola konsumsi gula, mengakibatkan Indonesia menjadi negara pengimpor gula untuk memenuhi kebutuhan seluruh permintaan gula nasional setiap tahunnya. Maka dari itu untuk menekan harga gula dalam negeri salah satu caranya yaitu dengan melakukan impor gula dari Negara lain seperti Thailand, untuk lebih jelasnya bisa dilihat pada Tabel 1. 
Tabel 1

Perkembangan Kinerja Industri Gula Indonesia

\begin{tabular}{cccc}
\hline Tahun & Konsumsi (Ton) & Harga $(\mathbf{R p} / \mathbf{K g})$ & Produksi (Ton) \\
\hline 2015 & 3.049 .007 & $12.570,75$ & 2.534 .872 \\
\hline 2016 & 3.458 .637 & $14.516,5$ & 2.363 .042 \\
\hline 2017 & 3.124 .358 & 12.500 & 1.210 .000 \\
\hline 2018 & 3.161 .633 & 12.385 & 2.100 .000 \\
\hline 2019 & 3.152 .230 & 12.834 & 2.450 .000 \\
\hline
\end{tabular}

Sumber : BPS Jatim (data diolah)

Berdasarkan tabel diatas, angka konsumsi gula di Indonesia meningkat pada tahun 2019 mencapai 3,15 juta ton, dapat dilihat dari tabel konsumsi yang semakin meningkat, hal ini akan terus meningkat apabila banyak industri makanan dan minuman yang memakai bahan baku utama gula (Statistik, 2018). Peningkatan konsumsi gula ini belum dapat diimbangi dengan peningkatan produksi. Hal ini diakibatkan oleh luasnya produktivitas yang juga menurun sementara konsumsi terus meningkat.

Selain diatas, harga gula di Indonesia pada lima tahun terakhir mengalami kenaikan dan penurunan yang signifikan. Harga gula di Indonesia cenderung mengalami kenaikan dan penurunan yang disebabkan oleh produksi gula dalam negeri yang masih kurang, serta bertambahnya jumlah penduduk yang pesat dan meningkatnya permintaan akan gula. Ketidakstabilan harga gula yang ada di Indonesia pada masa krisis merupakan akibat dari tingginya ketergantungan pemenuhan gula kita terhadap pihak luar, sehingga harga yang di dalam negeri sangat dipengaruhi oleh harga gula dunia.

Selain diatas, terlihat bahwa jumlah produksi gula tidak dapat mengimbangi jumlah permintaan dalam negeri yang terus-menerus meningkat setiap tahunnya, sehingga tidak dapat mencukupi kebutuhan masyarakat. Dalam 5 tahun terakhir produksi gula mengalami fluktuasi, dan produksi gula tertinggi sebanyak 2,56 juta ton yang terjadi pada tahun 2015. Produksi gula pasir mengalami penurunan salah satunya disebabkan karena adanya beberapa faktor yang diantaranya yaitu efisiensi pada suatu tingkat tanaman (on farm) yang masih sangat rendah dan efisiensi pabrik gula (off farm) yang dimana salah satunya yaitu mensi penggiling tebu yang sudah tua usianya sehingga produksi gula juga kurang maksimal (Mardianto et al., 2005).

Dalam rangka menjaga stabilitas harga gula di Indonesia perlu sekali memperhatikan kepentingan konsumen, dan perlu menetapkan tarif Bea Masuk atas impor gula. Surat keputusan Menteri Perindustrian dan Perdagangan No.230/MPP/Kep/6/199 yang memberlakukan tarif bea masuk sesuai dengan peraturan, baik itu importir umum maupun importir produsen yang diperbolehkan untuk mengimpor beras dan gula. Dengan adanya peraturan tersebut para importir harus membayar bea masuk impor sebesar $25 \%$.

Berdasarkan latar belakang yang telah dijelaskan oleh penulis dan menjelaskan beberapa faktor yang mempengaruhi jumlah impor gula di Indonesia. Dengan demikian penulis melakukan penelitian mengenai jumlah impor gula dan faktor-faktor yang mempengaruhinya di Indonesia dengan judul "Analisis Faktor Yang Mempengaruhi Impor Gula di Indonesia”. 
Tujuan dalam penelitian ini adalah untuk menganalisis pengaruh konsumsi gula terhadap terhadap impor gula di Indonesia, untuk menganalisis pengaruh harga gula terhadap impor gula di Indonesia, dan untuk menganalisis pengaruh produksi gula terhadap impor gula di Indonesia.

Penelitian ini menggunakan cara mengumpulkan data lalu mengolah datanya sehingga memecahkan masalah penelitian. Menurut (Surakhmad, 1990) metode penelitian merupakan cara yang digunakan untuk menghasilkan tujuan, contohnya untuk menguji hipotesa, dengan menggunakan alat-alat tertentu. Penelitian ini dilakukan untuk menganalisis pengaruh konsumsi gula, produksi gula, harga gula, bea masuk gula terhadap impor gula tahun 2002-2019. Variabel penelitian yaitu segala suatu bentuk yang ditetapkan oleh peneliti untuk dipelajari, sehingga memperoleh informasi tentang hal tersebut, dan kemudian dapat ditarik kesimpulannya (Sugiyono,2016). Maka dari itu penulis mengelompokan variabel-variabel yang digunakan di dalam penelitian ini menjadi variabel independen $(\mathrm{X})$ dan variabel dependen $(\mathrm{Y})$.

\section{Hasil dan Pembahasan}

\section{A. Hasil Penelitian}

Deskripsi hasil penelitian ini memberikan gambaran tentang data-data serta perkembangan impor gula yang ada di Indonesia, konsumsi gula, harga gula, produksi gula,dan bea masuk impor gula pada tahun 2002-2019 di Indonesia.

\section{Perkembangan Impor Gula di Indonesia}

Impor gula menjadi faktor penting yang sangat menguntungkan bagi perekonomian di Indonesia. Berikut adalah perkembangan impor gula di Indonesia periode 2002-2019 pada tabel 1 sebagai berikut.

Tabel 1

Perkembangan Impor Gula di Indonesia

Tahun 2002-2019

\begin{tabular}{ccc}
\hline Tahun & $\begin{array}{c}\text { Impor Gula } \\
\text { (Ton) }\end{array}$ & $\begin{array}{c}\text { Perkembangan } \\
(\%)\end{array}$ \\
\hline 2002 & 1425507 & - \\
\hline 2003 & 1596739 & 0,120 \\
\hline 2004 & 1230284 & $-0,229$ \\
\hline 2005 & 1104884 & $-0,101$ \\
\hline 2006 & 1405942 & 0,272 \\
\hline 2007 & 2972788 & 1,114 \\
\hline 2008 & 983944 & $-0,669$ \\
\hline 2009 & 1373527 & 0,395 \\
\hline 2010 & 1382525 & 0,006 \\
\hline 2011 & 2371250 & 0,715 \\
\hline 2012 & 2743778 & 0,157 \\
\hline 2013 & 3343803 & 0,218 \\
\hline 2014 & 2933823 & $-0,122$ \\
\hline 2015 & 3369941 & 0,148 \\
\hline 2016 & 1619433 & $-0,519$ \\
\hline 2017 & 4470000 & 1,760 \\
\hline
\end{tabular}




\begin{tabular}{ccc}
\hline 2018 & 3600000 & $-0,194$ \\
\hline 2019 & 4991020 & 0,386 \\
\hline \multicolumn{2}{r}{ Sumber } & BPS Jatim, 2019 (data diolah)
\end{tabular}

Dari tabel 1 dapat diambil kesimpulan bahwa dalam perkembangan impor gula di Indonesia pada kurun waktu 2002-2019 terus mengalami fluktuasi, angka tertinggi terjadi pada tahun 2017 sebesar 1,76\% dan perkembangan angka terendah pada tahun 2016 sebesar 0,52\%. Maka, hal ini menyebabkan Indonesia menjadi pengimpor gula terbesar kedua di dunia setelah Rusia (Sawit, 2003).

Menurut teori perdagangan internasional sejak lama diyakini oleh dunia sebagai pemberi sumbangan yang baik bagi pertumbuhan ekonomi sebuah Negara (Rahayu, 2018). terlebih dalam impor juga tidak lepas dari yang dinamakan harga. Karena harga juga mempengaruhi komoditas impor gula yang akan dijual kepada konsumen. Tetapi disisi lain Indonesia masih mengimpor gula, dikarenakan pesatnya laju peningkatan konsumsi gula tidak sebanding dengan laju peningkatan produksi secara nasional.

\section{Perkembangan Konsumsi Gula}

Konsumsi gula pasir di dalam negeri secara absolut cukup besar sekali, serta dari tahun ke tahun gula yang ada di Indonesia menunjukkan kecenderungan yang semakin meningkat juga. Berikut adalah perkembangan konsumsi gula di Indonesia tahun 2002-2019 pada tabel 2.

\section{Tabel 1}

Konsumsi Gula di Indonesia Tahun 2002-2019

\begin{tabular}{ccc}
\hline Tahun & $\begin{array}{c}\text { Konsumsi Gula } \\
\text { (Ton) }\end{array}$ & $\begin{array}{c}\text { Perkembangan } \\
(\%)\end{array}$ \\
\hline 2002 & 3180941 & - \\
\hline 2003 & 3228655 & 0,015 \\
\hline 2004 & 3281928 & 0,016 \\
\hline 2005 & 3324662 & 0,013 \\
\hline 2006 & 3760000 & 0,130 \\
\hline 2007 & 3759524 & $-0,001$ \\
\hline 2008 & 3500000 & $-0,069$ \\
\hline 2009 & 4300000 & 0,228 \\
\hline 2010 & 4534500 & 0,054 \\
\hline 2011 & 4670770 & 0,030 \\
\hline 2012 & 5200000 & 0,113 \\
\hline 2013 & 5516470 & 0,060 \\
\hline 2014 & 5700000 & 0,033 \\
\hline 2015 & 3049007 & $-0,465$ \\
\hline 2016 & 3458637 & 0,134 \\
\hline 2017 & 3124358 & $-0,096$ \\
\hline 2018 & 3161633 & 0,011 \\
\hline 2019 & 3152230 & $-0,003$ \\
\hline Sumber : BPS Jatim,2019 (data diolah)
\end{tabular}


Berdasarkan tabel 2 terlihat bahwa perkembangan konsumsi gula yang ada di Indonesia mengalami fluktuasi, perkembangan tertinggi terjadi pada tahun 2009 yang rata-rata kenaikkannya sebesar 0,228\% dan yang terendah tahun 2019 sebesar $-0,003 \%$. Perkembangan konsumsi yang terus meningkat dikarenakan konsumsi gula ini belum dapat diimbangi dengan peningkatan produksi yang diakibatkan oleh luasnya produktivitas yang menurun sementara konsumsi gula terus meningkat.

Berdasarkan teori konsumsi yang dikemukakan oleh Keynes bahwa pada saat pendapatan seseorang semakin tinggi maka semakin tinggi pula konsumsi dan tabungannya. Jika diterapkan penelitian ini, dengan semakin tinggi pendapatn seseorang maka semakin tinggi tingkat konsumsi seseorang akan gula pasir.

\section{Perkembangan Harga Gula}

Harga termasuk salah satu faktor pendukung di dalam permintaan akan suatu barang. Harga gula yang tinggi ini mengakibatkan adanya suatu kenaikkan permintaan. Berikut adalah perkembangan harga gula di Indonesia tahun 20022019 pada tabel 3.

Tabel 2

Harga Gula di Indonesia Tahun 2002-2019

\begin{tabular}{ccc}
\hline Tahun & $\begin{array}{c}\text { Harga Gula } \\
(\mathbf{R p} / \mathbf{K g})\end{array}$ & $\begin{array}{c}\text { Perkembangan } \\
(\mathbf{\%})\end{array}$ \\
\hline 2002 & 297022 & - \\
\hline 2003 & 432518 & 0,456 \\
\hline 2004 & 500000 & $-0,988$ \\
\hline 2005 & 550000 & 0,1 \\
\hline 2006 & 480000 & $-0,127$ \\
\hline 2007 & 490000 & 0,020 \\
\hline 2008 & 553900 & 0,130 \\
\hline 2009 & 535000 & $-0,034$ \\
\hline 2010 & 649900 & 0,214 \\
\hline 2011 & 1081842 & 165,46 \\
\hline 2012 & 1196142 & 0,105 \\
\hline 2013 & 1254100 & $-0,989$ \\
\hline 2014 & 1178275 & 92,953 \\
\hline 2015 & 1257075 & 0,066 \\
\hline 2016 & 1451650 & $-0,884$ \\
\hline 2017 & 1250000 & $-0,913$ \\
\hline 2018 & 1238600 & $-0,009$ \\
\hline 2019 & 1283400 & 0,036 \\
\hline & Sumber : BPS Jatim, 2019 (data diolah)
\end{tabular}

Berdasarkan table 3 terlihat bahwa harga gula di Indonesia dari tahun 2002 sampai 2019 mengalami fluktuasi, dengan perkembangan angka tertinggi pada tahun 2014 sebesar $92,953 \%$ dan yang terendah tahun 2018 yaitu $-0,009 \%$. Harga gula menunjukkan kenaikan yang mempengaruhi impo gula di Indonesia. Hal ini sesuai dengan penelitian yang dilakukan oleh (Zaini, 2008). 


\section{Perkembangan Produksi Gula}

Pasokan gula yang ada di Indonesia semua berasal dari produksi dalam negeri. Dapat dilihat perkembangan produksi gula di Indonesia pada tabel 4.

Tabel 4

Produksi Gula di Indonesia Tahun 2002-2019

\begin{tabular}{ccc}
\hline Tahun & $\begin{array}{c}\text { Produksi Gula } \\
\text { (Ton) }\end{array}$ & $\begin{array}{c}\text { Perkembangan } \\
(\%)\end{array}$ \\
\hline 2002 & 1755434 & - \\
\hline 2003 & 1631918 & $-0,070$ \\
\hline 2004 & 2051644 & 0,257 \\
\hline 2005 & 2219778 & 0,081 \\
\hline 2006 & 2289127 & 0,031 \\
\hline 2007 & 2157374 & $-0,057$ \\
\hline 2008 & 2694227 & 0,248 \\
\hline 2009 & 2517374 & $-0,065$ \\
\hline 2010 & 26600 & 0,056 \\
\hline 2011 & 24000 & $-0,097$ \\
\hline 2012 & 28700 & 0,195 \\
\hline 2013 & 28400 & $-0,010$ \\
\hline 2014 & 28600 & 0,007 \\
\hline 2015 & 2534872 & $-0,113$ \\
\hline 2016 & 2363042 & $-0,067$ \\
\hline 2017 & 12100 & $-0,487$ \\
\hline 2018 & 21000 & 0,735 \\
\hline 2019 & 24500 & 0,166 \\
\hline
\end{tabular}

Sumber : BPS Jatim, 2019 (data diolah)

Berdasarkan tabel 4 terlihat bahwa perkembangan produksi gula di Indonesia dari tahun 2002 sampai 2019 mengalami fluktuasi dan cenderung meningkat, dengan perkembangan tertinggi pada tahun 2018 sebesar $0,735 \%$ dan yang terendah pada tahun 2013 sebesar -0,010. Terlihat sangat jelas bahwa produksi gula di Indonesia tidak dapat mengimbangi jumlah permintaan dalam negeri yang terus-menerus meningkat, sehingga belum mencukupi kebutuhan masyarakat.

\section{Perkembangan Bea Masuk Gula}

Tabel 3

Bea Masuk Gula di Indonesia

Tahun 2002-2019

\begin{tabular}{ccc}
\hline Tahun & $\begin{array}{c}\text { Bea Masuk } \\
(\mathbf{R} \mathbf{p} / \mathbf{K g})\end{array}$ & $\begin{array}{c}\text { Perkembangan } \\
(\mathbf{\%})\end{array}$ \\
\hline 2002 & 400 & - \\
\hline 2003 & 400 & $0 \%$ \\
\hline 2004 & 440 & $10 \%$ \\
\hline 2005 & 490 & $11 \%$ \\
\hline 2006 & 550 & $12 \%$ \\
\hline 2007 & 550 & $0 \%$ \\
\hline
\end{tabular}




\begin{tabular}{ccc}
\hline 2008 & 750 & $36 \%$ \\
\hline 2009 & 750 & $0 \%$ \\
\hline 2010 & 790 & $5 \%$ \\
\hline 2011 & 550 & $-30 \%$ \\
\hline 2012 & 550 & $0 \%$ \\
\hline 2013 & 550 & $0 \%$ \\
\hline 2014 & 500 & $-9 \%$ \\
\hline 2015 & 550 & $10 \%$ \\
\hline 2016 & 550 & $0 \%$ \\
\hline 2017 & 550 & $0 \%$ \\
\hline 2018 & 550 & $0 \%$ \\
\hline 2019 & 550 & $0 \%$ \\
\hline
\end{tabular}

Sumber : BPS Jatim, 2019 (data diolah)

Dalam rangka untuk menjaga stabilitas harga gula di Indonesia perlu memperhatikan kepentingan konsumen serta perlu menetapkan tarif Bea Masuk atas impor gula. Dapat dilihat perkembangan bea masuk gula pada tabel 5 .

Berdasarkan tabel 5 terlihat bahwa perkembangan bea masuk gula di Indonesia dari tahun 2002-2019 mengalami fluktuasi dan cenderung menurun, dengan perkembangan tertinggi pada tahun 2008 sebesar $36 \%$ dan yang terendah pada tahun 2014 sebesar $-9 \%$. Penurunan tarif bea masuk gula yang sangat drastis ini untuk menekan lonjakan harga gula dalam negeri, maka dari itu pemerintah memutuskan untuk menurunkan tarif bea masuk.

\section{Analisis dan Pengujian Hipotesis}

Penelitian ini digunakan untuk mengukur kemampuan model dalam menjelaskan variasi variabel dependen. Koefisien determinasi ini adalah antara nol dan satu.

Tabel 4

Koefisien Determinasi

\begin{tabular}{cc}
\hline $\mathbf{R}$ & $\mathbf{R}$ Square \\
\hline 0,758 & 0,574 \\
\hline
\end{tabular}

Berdasarkan hasil analisis yang diperoleh dari pengolahan data menunjukkan korelasi antara variabel Konsumsi Gula (X1), Harga Gula (X2), Produksi Gula (X3), dan Bea Masuk (X4) terhadap Impor Gula di Indonesia diperoleh $=0,574$ yang artinya variabel-variabel independen hampir semua memberikan informasi yang dibutuhkan untuk memprediksi variasi variabel dependen. Persamaan regresi sebesar 57,4\% menunjukkan bahwa variabel Impor Gula di Indonesia yang dapat dijelaskan, sedangkan selebihnya yaitu 42,6\% dijelaskan oleh variabel diluar persamaan model ini.

\section{Analisis Regresi Linear Berganda}

Dalam penelitian ini digunakan analisis regresi linier berganda untuk mengolah suatu data yang ada dengan alat bantu komputer dan program SPSS (Statistic Program For Social Science). 
Berdasarkan hasil pengolahan data yang ada dengan bantuan program SPSS versi 13 maka diperoleh persamaan regresi linier berganda sebagai berikut :

$\mathrm{Y}=20108.147+0.059 \mathrm{X} 1+2.407 \mathrm{X} 2+-0.831 \mathrm{X} 3+-0.529 \mathrm{X} 4$

Berdasarkan persamaan diatas dapat diuraikan sebagai berikut :

$\beta_{0}$ : Nilai konstanta sebesar 20108.147

Menunjukkan apabila Konsumsi (X1), Harga Gula (X2), Produksi (X3), dan Bea Masuk (X4) dianggap konstan maka Impor Gula di Indonesia (Y) akan turun sebesar 20108.147 persen.

$\beta_{1}$ : Koefisien regresi $\mathrm{X} 1\left(\beta_{1}\right): \mathrm{Y}=0.059$

Menunjukkan bahwa Konsumsi $\left(\mathrm{X}_{1}\right)$ berpengaruh positif, yang artinya apabila konsumsi mengalami peningkatan sebesar 1 ton maka dari itu Impor Gula di Indonesia (Y) mengalami peningkatan sebesar 0.059 persen. Dengan asumsi yang dimana $\mathrm{X}_{2}, \mathrm{X}_{3}$, dan $\mathrm{X}_{4}$ Konstan.

$\beta_{2}$ : Koefisien regresi $\mathrm{X} 2\left(\beta_{2}\right): \mathrm{Y}=2.407$

Menunjukkan bahwa Harga Gula $\left(\mathrm{X}_{2}\right)$ berpengaruh positif, dapat diartikan apabila harga gula mengalami peningkatan sebesar 1 rupiah maka Impor Gula di Indonesia (Y) mengalami peningkatan sebesar 2.407 persen. Dengan asumsi yang dimana $\mathrm{X}_{2}, \mathrm{X}_{3}$, dan $\mathrm{X}_{4}$ Konstan.

$\beta_{3}$ : Koefisien regresi X3 $\left(\beta_{3}\right): Y=-0.831$

Menunjukkan bahwa Produksi $\left(\mathrm{X}_{3}\right)$ berpengaruh negatif, maka dapat diartikan apabila produksi mengalami peningkatan sebesar 1 ton maka Impor Gula di Indonesia (Y) mengalami penurunan sebesar 0.831 persen. Dengan asumsi yang dimana $\mathrm{X}_{2}, \mathrm{X}_{3}$, dan $\mathrm{X}_{4}$ Konstan.

$\beta_{4:}$ Koefisien regresi $X 4\left(\beta_{4}\right)=-0.529$

Menunjukkan bahwa Bea Masuk Impor Gula $\left(\mathrm{X}_{4}\right)$ berpengaruh negatif, dapat diartikan apabila Bea Masuk Impor Gula mengalami peningkatan 1 rupiah maka Impor Gula di Indonesia (Y) mengalamu penurunan sebesar 0.529 persen. Dengan asumsi yang dimana $\mathrm{X}_{2}, \mathrm{X}_{3}$, dan $\mathrm{X}_{4}$ Konstan.

\section{Pengujian Hipotesis}

Pengujian ini dilakukan untuk memperoleh hasil estimasi yang BLUE (Best Linier Unbiased Estimator) atau perkiraan linier tidak bias yang terbaik maka estimatimasi tersebut harus memiliki beberapa asumsi yang berkaitan. Apabila salah satu asumsi itu dilanggar, maka persamaan regresi tidak lagi bersifat $B L U E$, sehingga pengambilan keputusan melalui Uji F dan Uji t menjadi bias.

a. Uji Autokorelasi

Dari hasil analisis pada kedua persamaan untuk uji autokorelasi pada penelitian ini diperoleh nilai $D W$ test sebesar 1,833 . Untuk mengetahui ada tidaknya gejala autokorelasi dalam model penelitian maka dapat dibuktikan dengan kurva $D W$. 
1) Persamaan (Y)

Dalam persamaan I jumlah variabel bebas (k) adalah 4 dan banyaknya data (n) adalah 18 sehingga diperoleh nilai $D W$ tabel adalah sebesar $\mathrm{dL}=$ 0,8204 dan $\mathrm{dU}=1,8719$. Dapat dilihat pada kurva dibawah

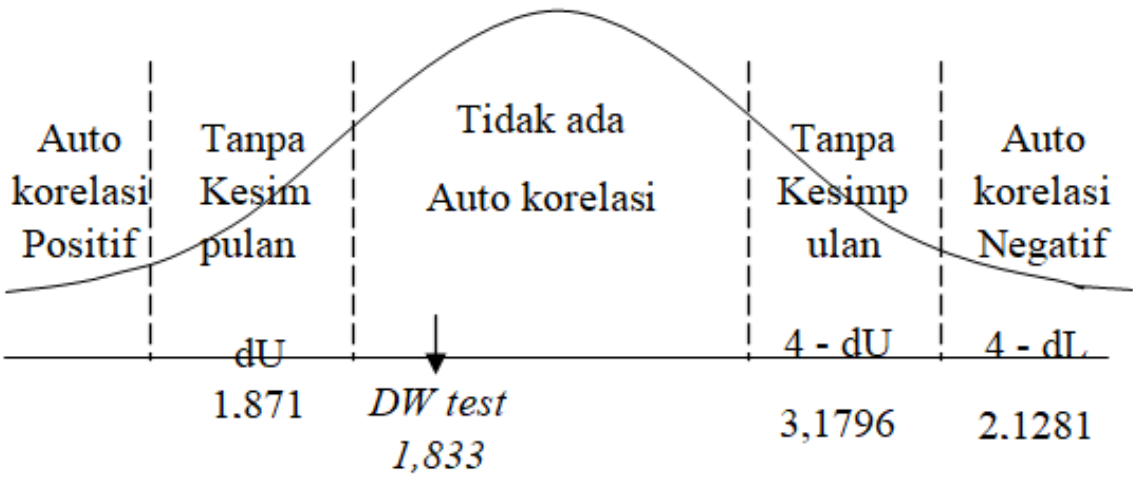

\section{Gambar 1}

Kurva DW Test Persamaan I (Y)

b. Multikolinieritas

Untuk mengetahui adanya hubungan linier yang aman diantara sejumlah atau semua variabel independen dari model regresi, hingga diperlukan adanya pembuktian secara statistik ada atau tidak adanya gejala multikolinier dengan melihat nilai VIF (Variance Inflation Factor) dari hasil analisis regresi dengan suatu ketentuan yang sudah dijelaskan pada bagian bab sebelumnya.

Adapun hasil yang diperoleh dari setelah dilakukan pengujian analisis regresi linier berganda diketahui dapat dilihat pada tabel berikut :

Tabel 5

Nilai TOL dan VIF Persamaan I (Y)

\begin{tabular}{cccccc}
\hline Variabel & Tolerance & Ketentuan & VIF & Ketentuan & Keterangan \\
\hline $\mathrm{X}_{1}$ & 0,522 & $\geq 0,1$ & 1,915 & $\leq 10$ & $\begin{array}{r}\text { Tidak Terjadi } \\
\text { Multikolinier }\end{array}$ \\
\hline $\mathrm{X}_{2}$ & 0,912 & $\geq 0,1$ & 1,096 & $\leq 10$ & $\begin{array}{r}\text { Tidak Terjadi } \\
\text { Multikolinier }\end{array}$ \\
\hline $\mathrm{X}_{3}$ & 0,413 & $\geq 0,1$ & 2,418 & $\leq 10$ & $\begin{array}{c}\text { Tidak Terjadi } \\
\text { Multikolinier }\end{array}$ \\
\hline $\mathrm{X}_{4}$ & 0,746 & $\geq 0,1$ & 1,340 & $\leq 10$ & $\begin{array}{c}\text { Tidak Terjadi } \\
\text { Multikolinier }\end{array}$ \\
\hline
\end{tabular}

Sumber : Lampiran (Output SPSS)

c. Heterokedastisitas

Uji heterokedastisitas bertujuan mencoba apakah bermakna model regresi berjalan ketidaksamaan varian dari residual satu pengamatan ke penglihatan lain. Pada regresi linier nilai residual tidak boleh adanya hubungan dengan variabel (X). Heteroskedastisitas diuji dengan menggunakan uji koefisien korelasi Rank Spearman yaitu mengkorelasikan antara absolut residual hasil 
regresi dengan semua variabel bebas. Hasil uji heteroskedastisitas dapat dilihat pada tabel dibawah ini:

Tabel 6

Korelasi Rank Spearman

\begin{tabular}{ccccccc}
\hline $\begin{array}{c}\text { Variabel } \\
(\mathbf{Y})\end{array}$ & $\begin{array}{c}\text { Sig } \\
\mathbf{2 -} \\
\text { tailed } \\
\left(\mathbf{X}_{\mathbf{1}}\right)\end{array}$ & $\begin{array}{c}\text { Sig } \\
\mathbf{2 -} \\
\text { tailed } \\
\left(\mathbf{X}_{\mathbf{2}}\right)\end{array}$ & $\begin{array}{c}\text { Sig } \\
\mathbf{2 -} \\
\text { tailed } \\
\left(\mathbf{X}_{\mathbf{3}}\right)\end{array}$ & $\begin{array}{c}\text { Sig } \\
\mathbf{2 -} \\
\text { tailed } \\
\left(\mathbf{X}_{\mathbf{4}}\right)\end{array}$ & Ketentuan & Keterangan \\
\hline Impor & 0,463 & 0,280 & 0,766 & 0,684 & $\geq 0,05$ & \\
Gula & & & & & & Tidak Terjadi \\
Heterokedastisitas \\
\hline
\end{tabular}

Sumber : Output SPSS

\section{Uji F}

Untuk melihat adanya pengaruh atau jaringan sebagai simultan maka digunakan uji $\mathrm{F}$, dari perhitungan dengan menggunakan program SPSS maka diperoleh hasil perhitungan ANOVA sebagai berikut:

a. Uji F Persamaan (Y)

Tabel 7

ANOVA Persamaan I (Y)

\begin{tabular}{cccccc}
\hline Model & $\begin{array}{c}\text { Sum of } \\
\text { Squares }\end{array}$ & Df & $\begin{array}{c}\text { Mean } \\
\text { Square }\end{array}$ & F & Sig \\
\hline Regression & $1 \mathrm{E}+009$ & 4 & 363718327,1 & 4.386 & $.018^{\mathrm{a}}$ \\
\hline Residual & $1 \mathrm{E}+009$ & 13 & 82928938,99 & & \\
\hline Total & $3 \mathrm{E}+009$ & 17 & & & \\
\hline \multicolumn{6}{c}{ Sumber : Output SPSS }
\end{tabular}

Pada tabel ANOVA persamaan I diperoleh nilai F hitung sebesar 4,386 dengan tingkat signifikan sebesar $0.018 \mathrm{a}$, sedangkan nilai $\mathrm{F}$ tabel $(\alpha=0,05)$ dengan degree of freedom (df1) 4 (jumlah variabel bebas/k) dan df2 18 (n-k-1) maka diperoleh nilai $\mathrm{F}$ tabel sebesar 2,93. Dari hasil tersebut diketahui nilai $\mathrm{F}$ hitung $\geq \mathrm{F}$ tabel. Berikut adalah penjelasan dari kurva dibawah, maka dapat disimpulkan secara silmultan variabel Konsumsi Gula (X1), Harga Gula (X2), Produksi Gula (X3), dan Bea Masuk (X4) berpengaruh secara signifikan dan positif terhadap Impor Gula (Y).

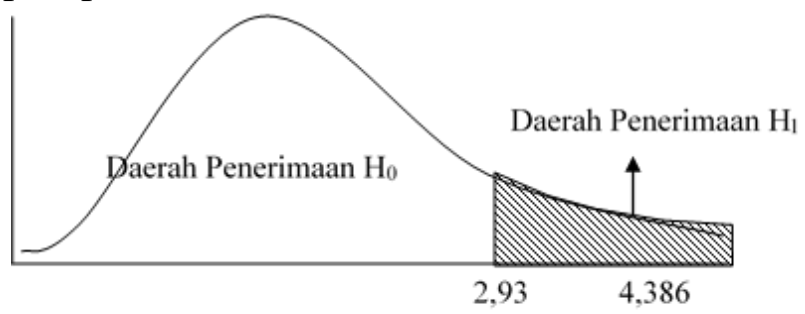

Gambar 2

Kurva Distribusi Uji F Persamaan I (Y) 
10. Uji t

Pada uji t ini digunakan untuk melihat pengaruh signifikan variabel bebas sebagai individual terhadap variabel terikat. Hasil dari uji t dalam penelitian ini dijelaskan sebagai berikut :

Tabel 8

Hasil Analisis Uji t

\begin{tabular}{ccc}
\hline Variabel & t Hitung & t Tabel \\
\hline Konsumsi Gula $\left(\mathrm{X}_{1}\right)$ & 0,169 & 2,160 \\
\hline Harga Gula $\left(\mathrm{X}_{2}\right)$ & 4,109 & 2,160 \\
\hline Produksi Gula $\left(\mathrm{X}_{3}\right)$ & $-1,084$ & 2,160 \\
\hline Bea Masuk $\left(\mathrm{X}_{4}\right)$ & $-0,022$ & 2,160 \\
\hline
\end{tabular}

Sumber : Output SPSS

a. Variabel Konsumsi Gula $\left(\mathrm{X}_{1}\right)$

Dari perhitungan secara parsial diperoleh nilai t hitung sebesar 0,169 sedangkan nilai t tabel $(\alpha / 2=0,025)$ dengan degree of freedom $(d f) 4(\mathrm{n}-\mathrm{k}-1)$ diperoleh nilai t tabel sebesar 2,160. Dari hasil tersebut diketahui bahwa nilai $\mathrm{t}_{\text {hitung }} 0,169 \leq \mathrm{t}_{\text {tabel }} 2,160$ dengan dibuktikannya pada kurva distribusi uji $\mathrm{t}$. Berdasarkan kurva dibawah ini maka dapat disimpulkan bahwa Konsumsi Gula secara parsial tidak berpengaruh terhadap Impor Gula di Indonesia.

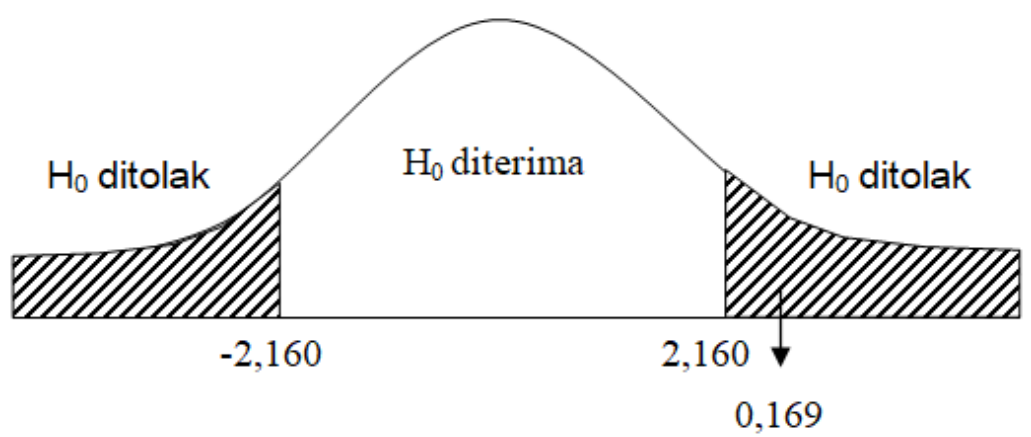

Gambar 2

Kurva Distribusi Uji t Konsumsi gula $\left(\mathbf{X}_{1}\right)$

b. Variabel Harga Gula $\left(\mathrm{X}_{2}\right)$

Dari perhitungan secara parsial diperoleh nilai t hitung sebesar 4,109 sedangkan nilai t tabel $(\alpha / 2=0,025)$ dengan degree of freedom $(d f) 4(\mathrm{n}-\mathrm{k}-1)$ diperoleh nilai t tabel sebesar 2,160. Dari hasil tersebut diketahui bahwa nilai $\mathrm{t}_{\text {hitung }} 4,109 \geq \mathrm{t}_{\text {tabel }} 2,160$ dengan dibuktikannya pada kurva distribusi uji $\mathrm{t}$. Berdasarkan kurva dibawah ini maka dapat disimpulkan bahwa Harga Gula secara parsial berpengaruh terhadap Impor Gula di Indonesia. 


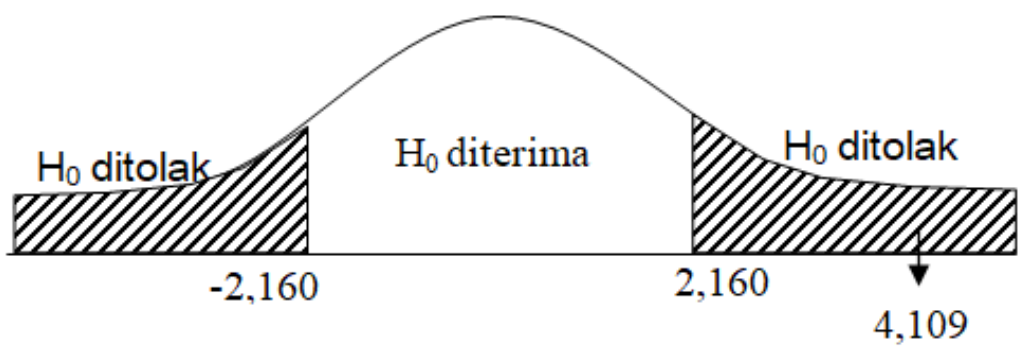

\section{Gambar 3}

\section{c. Variabel Produksi Gula $\left(\mathrm{X}_{3}\right)$}

Dari perhitungan secara parsial diperoleh nilai t hitung sebesar -1,084 sedangkan nilai t tabel $(\alpha / 2=0,025)$ dengan degree of freedom $(d f) 4(\mathrm{n}-\mathrm{k}-1)$ diperoleh nilai t tabel sebesar 2,160. Dari hasil tersebut diketahui bahwa nilai $t_{\text {hitung }}-1,084 \leq \mathrm{t}_{\text {tabel }} 2,160$ dengan dibuktikannya pada kurva distribusi uji $\mathrm{t}$. Berdasarkan kurva dibawah ini maka dapat disimpulkan bahwa Produksi Gula secara parsial tidak berpengaruh terhadap Impor Gula di Indonesia.

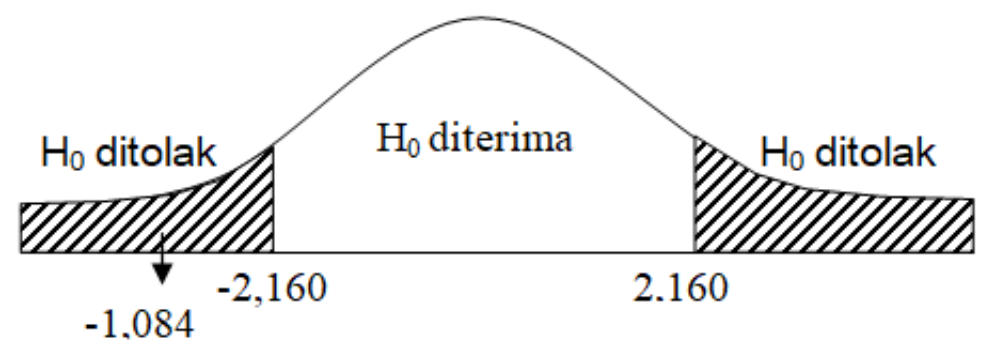

\section{Gambar 4}

d. Bea Masuk $\left(\mathrm{X}_{4}\right)$

\section{Kurva Distribusi Uji t Produksi Gula $\left(\mathbf{X}_{3}\right)$}

Dari perhitungan secara parsial diperoleh nilai t hitung sebesar $-0,022$ sedangkan nilai t tabel $(\alpha / 2=0,025)$ dengan degree of freedom $(d f) 4(n-k-1)$ diperoleh nilai t tabel sebesar 2,160. Dari hasil tersebut diketahui bahwa nilai $t_{\text {hitung }}-0,022 \leq \mathrm{t}_{\text {tabel }} 2,160$ dengan dibuktikannya pada kurva distribusi uji t. Berdasarkan kurva dibawah ini maka dapat disimpulkan bahwa Bea Masuk secara parsial tidak berpengaruh terhadap Impor Gula di Indonesia.

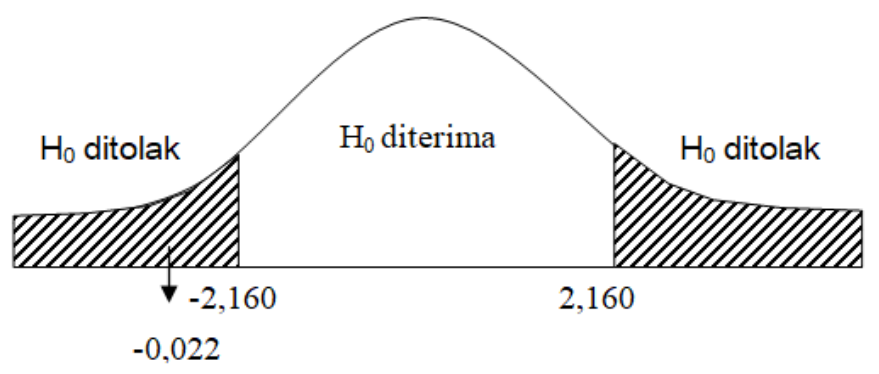

Gambar 6

Kurva Distribusi Uji t Bea Masuk (X4) 


\section{B. Pembahasan}

Tingkat Impor Gula di Indonesia dalam masa waktu 18 tahun mulai tahun 2002-2019 mengalami peningkatan presentase yang berbeda setiap tahun. Perkembangan Impor Gula di Indonesia Dipengaruhi oleh faktor-faktor berikut, di antaranya: Konsumsi Gula, Harga Gula, Produksi Gula, dan Bea Masuk. Namun ternyata dalam hal ini belum dapat dipastikan bahwa tidak semua variabel independen bermakna signifikan terhadap variabel dependen.

Bersumber hasil dari penelitian yang dilakukan bahwa variabel Konsumsi Gula tidak berpengaruh signifikan terhadap Impor Gula di Indonesia periode 2002-2019. Hal ini menunjukkan bahwa kenaikan Konsumsi Gula tidak mempengaruhi Impor Gula di Indonesia. Hal ini sesuai dengan penelitian yang dilakukan oleh (Wiranata, 2014) yang menjelaskan bahwa konsumsi gula tidak memiliki pengaruh signifikan terhadap impor gula.

Berdasarkan hasil dari penelitian yang dilakukan bahwa variabel Harga Gula berpengaruh signifikan terhadap Impor Gula di Indonesia periode 2002-2019, bahwa Harga Gula menunjukkan kenaikan yang mempengaruhi Impor Gula di Indonesia. Hal ini sesuai dengan penelitian yang dilakukan oleh (Zaini, 2008) yang menjelaskan bahwa harga gula memiliki pengaruh bermakna terhadap permintaan impor.

Berdasarkan hasil dari penelitian yang dilakukan bahwa variabel Produksi Gula tidak berpengaruh signifikan terhadap Impor Gula di Indonesia periode 2002-2019, bahwa Produksi Gula menunjukkan bahwa kenaikkan Produksi Gula tidak mempengaruhi Impor Gula di Indonesia. Hal ini sesuai menggunakan penelitian yang dilakukan oleh (Dachliani, 2006) dalam penelitiannya menjelaskan bahwa pengaruh produksi terhadap impor berpengaruh negatif secara signifikan. Artinya, pergantian satu persen produksi yang ada di dalam negeri, akan menyebabkan penurunan volume gula. Disebabkan sebab impor dilakukan jika suatu produk tidak memadai untuk kebutuhan dalam negeri.

\section{Kesimpulan}

Bersumber produk yang diperoleh Investigasi Faktor-Faktor yang Mempengaruhi Impor Gula Indonesia pada tahun 2002-2019 Dia menyimpulkan sebagai berikut: 1) Dengan melihat hasil uji signifikan variabel independen impor gula diketahui Bagian variabel konsumsi tidak berpengaruh secara penting terhadap impor gula di indonesia. hal ini disebabkan oleh luasnya produktivitas yang menurun sementara konsumsi gula terus meningkat. 2) Dengan melihat hasil uji signifikan variabel independen impor gula diketahui bahwa variabel harga gula secara parsial berpengaruh positif dan signifikan terhadap impor gula di Indonesia. Hal ini disebabkan karena pada saat harga naik impor gula sangat diperlukan untuk menstabilkan harga pada tingkatan yang bisa dijangkau oleh masyarakat. 3) Dengan melihat hasil uji signifikan variabel independen impor gula diketahui bahwa variabel produksi secara parsial tidak berpengaruh secara signifikan terhadap impor gula di Indonesia. Hal ini disebabkan karena kebijakan pergulaan yang tidak menentu dan ketertinggalan teknologi untuk produksi. 4) Dengan melihat hasil uji 
Analisis Faktor yang Mempengaruhi Impor Gula Di Indonesia

signifikan variabel independen impor gula diketahui bahwa variabel bea masuk secara parsial tidak berpengaruh secara signifikan terhadap impor gula di Indonesia. 


\section{BIBLIOGRAFI}

Aushaf, R., Juliprijanto, W., \& Septiani, Y. (2020). Faktor-Faktor Yang Mempengaruhi Impor Gula Di Indonesia Tahun 1989-2018. Dinamic: Directory Journal of Economic, 2 (3), 700-716. Google Scholar

Dachliani, D. M. (2006). Permintaan Impor Gula Indonesia Tahun 1980-2003. Program Pascasarjana Universitas Diponegoro. Google Scholar

Hairani, R. I., Aji, J. M. M., \& Januar, J. (2014). Analisis Trend Produksi Dan Impor Gula Serta Faktor-Faktor Yang Mempengaruhi Impor Gula Indonesia. Berkala Ilmiah Pertanian, 1 (4), 77-85. Google Scholar

Indonesia, D. G. (2009). Kondisi Pergulaan Indonesia. Bahan Rapat Teknis. Sekretariat Dewan Gula Indonesia. Jakarta. Google Scholar

Mardianto, S., Simatupang, P., Hadi, P. U., Malian, H., \& Susmiadi, A. (2005). Peta Jalan (Road Map) Dan Kebijakan Pengembangan Industri Gula Nasional. Google Scholar

Pertanian, D. (2008). Renstra Badan Litbang Pertanian 2005-2009. Google Scholar

Rahayu, S. R. I. E. (2018). Analisis Perkembangan Impor Gula Di Indonesia. Jepa, 2 (2), 1-10. Google Scholar

Sawit, M. H. (2003). Indonesia Dalam Perjanjian Pertanian Wto: Proposal Harbinson. Analisis Kebijakan Pertanian, 1(1), 42-53. Google Scholar

Statistik, B. P. (2018). Badan Pusat Statistik. Retrieved May, 11. Google Scholar

Sugiyono. (2016). Metode Penelitian Kuantitatif, Kualitatif Dan R\&D. PT Alfabet. Google Scholar

Surakhmad, W. (1990). Pengantar Penelitian Ilmiah: Dasar, Metode Dan Teknik. Tarsito. Google Scholar

Wiranata, Y. S. (2014). Faktor-Faktor Yang Mempengaruhi Impor Gula Pasir Di Indonesia Tahun 1980-2010. Economics Development Analysis Journal, 3 (4). Google Scholar

Yunitasari, D., Hakim, D. B., Juanda, B., \& Nurmalina, R. (2015). Menuju Swasembada Gula Nasional: Model Kebijakan Untuk Meningkatkan Produksi Gula Dan Pendapatan Petani Tebu Di Jawa Timur. Jurnal Ekonomi \& Kebijakan Publik, 6 (1), 1-15. Google Scholar

Yusuf, Y., \& Aulia, A. F. (2010). Permintaan Gula Pasir Di Indonesia. Jurnal Ekonomi, 18 (03). Google Scholar 
Zaini, A. (2008). Pengaruh Harga Gula Impor, Harga Gula Domestik Dan Produksi Gula Domestik Terhadap Permintaan Gula Impor Di Indonesia. Ekonomi Pembangunan Dan Perencanaan, 5 (2), 1-9. Google Scholar

\section{Copyright holder:}

Herawati Rusdi, Wiwin Priana Primandhana, Mohammad Wahed (2021)

First publication right:

Jurnal Syntax Admiration

This article is licensed under:

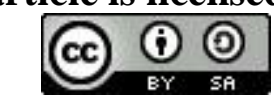

